\title{
Journalistic Stance in Newswriting on Iranian Nuclear Issue
}

\author{
Mohammad Hossein Ghane ${ }^{1} \&$ Fatemeh Mahdavirad ${ }^{1}$ \\ ${ }^{1}$ Yazd University, Iran \\ Correspondence: Mohammad Hossein Ghane, Yazd University, Iran. E-mail: Ghane57@yahoo.com
}

$\begin{aligned} & \text { Received: September 11, } 2016 \\ & \text { Accepted: September 30, } 2016 \quad \text { Online Published: November 23, } 2016 \\ & \text { doi:10.5539/ijel.v6n6p118 }\end{aligned} \quad$ URL: http://dx.doi.org/10.5539/ijel.v6n6p118

\begin{abstract}
Regarding the role of Critical Discourse Analysis (CDA) in discovering the way ideology is crystalized through the prevalence of various discourses, the present study is an attempt to examine how the journalistic personal and institutional ideologies and political positions are realized through certain textual and intertextual features. Using Perrin's (2012) progression model, journalistic stancing with regard to the Iranian nuclear issue at three levels of micro, meso, and macro was investigated. The study of claims of unpeacefulness in the Western media texts under investigation reveals a systematic ideological bias towards portraying a negative presentation of Iranian nuclear policy. The Iranian journalists, however, tend to highlight the peaceful nature of the Iranian nuclear program and the West's double standards as well as Iran's efforts in order to come to a mutual agreement. Implications of the insights provided by the study for confirming the premises of CDA and applications of the findings for teaching are explained in brief.
\end{abstract}

Keywords: critical discourse analysis, Iranian nuclear issue, media discourse, progression model, stancing

\section{Introduction}

The last decade of the 20th century has seen the rise of systematic studies of media discourse, particularly resulting from the increasing interest in studying the influence of media on their audience (Fairclough, 1995a \& b; van Dijk, 1998; Richardson, 2007). Following this trend, a variety of linguistic resources through which journalists can discursively encode their personal or institutional ideas, attitudes or opinions about the topics they cover have been studied.

A controversial and newsworthy area in the media discourse at least in the last decade has been Iran's nuclear activities. After Iran's Islamic Revolution in 1979 and toppling the Iranian Shah as a strict follower of the U.S policies in the Middle East, the U.S.A canceled Iran's nuclear contract. Accordingly, Iran tried to sign new contracts with other countries in order to continue its nuclear activities which caused tensions between Iran and the western countries which wanted Iranians to halt their nuclear activities. In order to achieve this aim, since 2002, there have been a number of negotiations between Iranian officials and the Western side of the conflict.

In this respect, the state-run media of both sides covered the negotiation developments vastly favoring their own institutionalized policies. To achieve their long run policies, media require public support which they try to gain through convincing discourse.

Among the various notions related to this issue, this paper will focus on stancing in news reporting. Therefore, this study is an attempt to contribute to the research on media language and news discourse analysis, as it explores the way Iranian and Western media differ in employing stance markers in order to steer the readers' views regarding the long-running international dispute over Iran's nuclear program to the direction they favor.

\section{Literature Review}

\subsection{Media Discourse}

Media language has long been a popular research focus for linguists who work with language and communication or media studies. It has been so, because it is highly and easily accessible, greatly influences and reflects people's use of language and their attitudes towards it, and is a rich source for social meanings (Bell \& Garrett, 1998).

Journalistic discourse has been analyzed linguistically from different aspects. Fowler (1991) believed that "the language devices used in newspapers, which were the constructive mediators, presented different ideas and beliefs to readers" and that "different aspects of linguistics structure contributed to ideological significance" (p. 
67).

Fairclough (1995b) connected the linguistic features with social values, in order to investigate the ideologies conveyed in news coverage and the relationship between power and inequality.

As van Dijk (1995) mentions media try to control people's minds, that is, their intentions, plans, knowledge, beliefs, or opinions in order to (indirectly) control their actions. As he further states, media manipulation is paramount when the media users are unaware of being influenced. He believes this can be explored on the basis of results of text linguistics and discourse analysis.

\subsection{Journalistic Stancing}

Findings of research studies on critical discourse analysis which focused on the discourse of newspapers (e.g., Hodge \& Kress, 1979; Van Dijk, 1998) show that media texts are carriers of attitudes and ideologies in favor of the elite. Naturally, events are not represented in media as they are in reality but go through journalistic practices such as stancing.

Perrin (2012) defines stancing as "the practice of taking and encoding a particular position" (p. 135). According to Perrin (2011) position refers to "implicit or explicit commitments that are based on judgments, assessments and, therefore, are related to subjective properties such as opinions, attitudes, and emotions" (p. 1865). Perrin (2011) further states that in journalism, positions are encoded through collaborative practices of text production within individual, organizational, institutional, and societal frames of reference. The process of encoding stance is guided by professional values and principles such as audience design (Bell, 2001), which focuses on the way journalists deploy linguistic resources to create styles and newsworthiness (Schultz, 2007). Stance, however, extends beyond linguistic means. On the one hand, it is expressed through semiotic systems such as visual signs (Economou, 2008), especially in video genres such as television news (Pounds, 2010). On the other hand, it results in consequences far beyond formulations which will be briefly explained in the progression model (section three).

\subsection{Critical Discourse Analysis (CDA)}

Based on CDA, the underlying ideologies in a society are reflected and produced through various linguistic devices (Stamou, 2001; Fairclough \& Wodak, 2007; Baker, 2008). According to van Dijk (1995), it specifically focuses on relations of power, dominance, and inequality in text and talk. van Dijk (1995) further points out what is distinctive about CDA compared with other approaches to research is that "it openly and explicitly positions itself on the side of dominated and oppressed groups and against dominating groups" (p. 18). In fact, CDA scholars focus on "the morally illegitimate forms of discursive mind control in text and talk" (p. 18) to resist their power in manipulating and influencing people's world views in the interest of the powers resulting in inequality.

There have been some discourse analysis studies, dealing with ideological representations on the Iranian nuclear issue in media, stipulating that linguistic tools are among the most important devices through which ideological tendencies are presented in media. Izadi \& ShaghayeBiria (2007), for instance, revealed how three elite American newspapers The New York Times, The Washington Post, and The Wall Street Journal selectively framed the issues surrounding the Iranian nuclear dispute by employing linguistic, stylistic, and argumentative maneuvers. They stressed the uniformity of the newspapers' ideological position in challenging the Iranian nuclear issue despite their different political line of vision in other areas. They found that it is due to the Islamic nature of the Iranian government that westerners regard it as a threat and do not trust it with sensitive nuclear technology. As another example, Shojaei, Youssefi, \& Shams Hosseini (2013), clarifying how linguistic tools can carry ideological traits in their discoursal properties, showed that newspapers play particularly important roles in representing and interpreting news stories. Analyzing some excerpts from some US and UK newspapers, they found that the language of western newspapers is highly ideological while representing the news of conflicting ideas between Iran and western countries. Finally, Talebinejad \& Shahi (2014) investigated the translation of rival names and labeling in Iranian state-run news agencies. They maintained that some names or labels adopted by the English news agencies were substituted with the names endorsed by the institutions in which the translators worked. They demonstrated that name substitution took place when Iran's national and international interests were conflicting with those of the West suggesting the translations to be ideologically driven.

Employing critical discourse analysis, the study of journalistic stance in newswriting in some of the Iranian and Western media is specifically chosen for the present paper. This is due to the fact that, although a great deal of studies have been conducted on the Iranian nuclear issue, little research, if any, have investigated, compared and contrasted the way Iranian and Western media endeavor to influence people's minds without them being aware 
of this manipulation. In other words, this study tries to reveal the journalistic practices of stancing through the discursive devices of argumentation and persuasion.

\section{Methodology}

\subsection{Materials}

Staying alert on the release of news on the nuclear negotiations, the researchers downloaded some texts from four Iranian and four Western online media through Google web search engine. In this regard, attempt was made for the corpus to include a similar proportion of Western and Iranian news texts, so it would be balanced and representative of both side news discourse about Iran's nuclear program. As a consequence, the validity of the very general conclusions the researchers arrived at can be confirmed. The texts were from March 19 to December 18, 2014.

The news and opinion coverage of the four Iranian media examined in this study included: Press TV, Tehran Times, Fars News Agency, and IRDIPLOMACY. These media were selected because they are of the most famous and influential in Iran and also outside Iran, especially that they are all state- run and represent the Iranian government. They may have some different viewpoints and perspectives regarding the Iranian nuclear program; however, since the nuclear program in Iran is a national issue, they produce the same voice.

The news and opinion coverage of the four Western media examined in this study included: The New York Times, Washington Post, The Jerusalem Post, and The Guardian. These media were selected because they include some of the largest news agencies in the United States, as well as those widely covering foreign policy issues in the United States, Britain, and Israel, as a follower of Western policies in the Middle East. Each of the papers also represents a distinct political and ideological perspective, including perspectives that favor international intervention in Iran and those that are of the idea to adhere to the international institutions to address the dispute. However, the point in which they are all united is that Iran should be stopped from making nuclear progress.

The texts from which the researchers selected the extracts were of news report and editorial types. The writers of the selected texts were journalists or correspondents, i.e., they were not MPs, representatives of governments, government spokesmen or officials of any government administrations.

\subsection{Instrument}

In this study, we adopted Perrin's (2012) progression model which investigates the journalistic stancing practices on three levels of micro, meso, and macro, as follows:

\section{Micro level:}

On a micro level, stancing refers to an individual journalist's strategies, practices, or routines. Perrin (2003) points out that writing strategies determine the idea of how decisions are to be made during the act of writing so that at the end the intended function has been fulfilled. In other words, authors use specific terms seeking to influence our conceptions. With regard to this level, 115 extracts are analyzed to account for the procedures through which the lexical features of (un)peacefulness were used to carry the intentions embedded in linguistic representations.

\section{Meso level:}

A critical approach to discourse is trying to discover the interaction between the situated micro activity of stancing and the social macro structures by means of the collaborative text (re-) production i.e., meso level (Perrin, 2012). In other words, "a text, an account of something that is taking place in a larger social context in which there is a complex set of power relations, is interpreted by readers or listeners depending on the rules, norms, and cognition of the people of the society they live in" (Behnam \& Mahmoudi, 2013, p. 2198). Therefore, based on people's cognition, media come up with lots of argumentation and persuasion in order to influence them. By comparing and analyzing the language used in these 115 extracts, an attempt is made to unveil such discursive strategies of argumentation and persuasion some of which are explicitly articulated and others implicitly.

\section{Macro level:}

Perrin (2012) states that stancing refers to "the institutional role and position" media play in "the intertextual chains of news flows and public discourse" (p. 136). In this regard, he further mentions: "Some utterances from sources are ignored or rejected while others are selected and offered to target audiences in order to generate value in information markets" (p. 136). Naturally, the values media try to generate are normally based on the national and international benefits for the powers. Through ethnographic information and analyzing intertextual relationship of the extracts it is discussed how the value generation is practiced throughout these extracts. 


\subsection{Procedure}

When the corpus was accumulated to 115 texts, the researchers selected the related extracts from the texts for analysis. The researchers' criterion for selecting the extracts was that they needed to be covering the same issues related to the Iranian nuclear program from both sides, so that they were comparable and the results could be generalizable.

In this regard, the selected extracts (approximately 3500 words) were juxtaposed in a way that was thematically parallel so that the Iranian and the Western media could be compared and contrasted. Some examples in this respect are demanding sanctions relief, expressing Iran's right to nuclear energy, an extension of the talks, uranium enrichment, etc.

The extracts selected ranged from two to six clauses in order to save energy and time and just to cover the nuclear issues. As it is common, political texts normally cover several issues at the same time; naturally, analyzing them all at the same time may create complexities as far as discourse analysis is concerned. But, as the role of context is significant, the extracts had to be meticulously selected in order to engulf the readers in the same contextual conditions, however limited, so that a good understanding would result.

In order to reduce any bias or arbitrariness, we divided the extracts between the two researchers randomly and after analysis we computed inter-rater reliability. Moreover, to make the analysis more accurate and to improve its reliability, one of the researchers reanalyzed all the extracts with a time interval of about one month and also calculated the intra-rater reliability using Cronbach's alpha. The slight differences did not affect the result and conformity was achieved for both inter and intra-rater reliability and the calculated Cronbach's alphas were 0.91 and 0.89 respectively.

Identifying the textual and intertextual features, we analyzed and interpreted them according to the progression model introduced by Perrin (2012) in order to identify the journalistic stancing practices in the levels of micro, meso, and macro through which the writers tried to convey their ideologies to their readers.

Whereas the dominant approach in this study was qualitative, there were, nonetheless, quantitative aspects to the study in terms of quantifying the number of (un)peacefulness terms employed by the Iranian and Western side to lead to a better understanding of either side's orientation in this regard. Counting the frequencies of such terms, the possible differences between the Iranian and the Western sides were detected to determine whether these differences were significant.

At this point, it should be pointed out that in the course of this study, we exploited our background knowledge as well and tried to decipher what the journalists meant which revealing their ideologies. So, the subjective nature of the analysis is obvious. According to Thelta (1997), identification and coding in text and discourse are not always straightforward. In fact, in some cases there is no clear cut borderline between the classification of the categories. For instance, in the present research, the terms suggesting either peacefulness or unpeacefulness were determined on a subjective basis by the researchers.

\section{Qualitative Analysis}

\subsection{Data Analysis and Discussion at Micro Level}

At micro level the extracts were analyzed in terms of terminologies dealing with peacefulness and unpeacefulness claims as a strategy of the journalists in order to affect the readers' views. All the words related to claims of peacefulness and unpeacefulness of the Iranian nuclear program were searched in the extracts taken from the Iranian and Western media carefully for the most frequent ones to be found.

From among the many peacefulness words in the Iranian media, the word peaceful and the phrases peaceful nuclear rights, nuclear rights, nuclear activities, nuclear program, nuclear talks, and nuclear deal were the most frequent ones. In the Western media, however, this class of terms included peaceful, peaceful energy purposes, nuclear fuel, nuclear activities, nuclear capabilities, and nuclear talks.

As to the unpeacefulness class of words in the Iranian media, the terms nuclear weapons, nuclear bombs, and concern were sparsely met. The Western media, however, were abundant with this class of words in an eye catching way. Some of the words and the phrases in this regard are as follows: nuclear weapons, atomic weapons, atomic bombs, concern, suspicion and suspect, and threat of war.

The above mentioned expressions in the media can be taken as evidence that the Iranian media emphasize the peaceful nature, while the Western media stress that the Iranian nuclear activities are unpeaceful.

Some of the extracts which include the terminology regarding the peacefulness of the Iranian nuclear activities are as follows: 


\section{Iranian Media Extracts}

Extract-1 Zarif said Tehran will not compromise on its peaceful nuclear rights (Press TV, 14 June, 2014).

Extract-2 We are willing to provide assurances of the exclusively peaceful nature of our nuclear program Araqchi said. (IRIDIPLOMACY, 14 June, 2014).

Extract-3 "We recognize Iran's inalienable right to the peaceful use of nuclear energy in a manner consistent with its international obligations," the leaders of the BRICS group (Brazil, Russia, India, China, and South Africa) said in a statement. (Tehran Times, 17 July, 2014).

In the following, there are some of the extracts from the Western media having claims of unpeacefulness of the Iranian nuclear program.

\section{Western Media Extracts}

Extract-4 Iran is a terrorist power...Netanyahu said. "This Iran cannot be allowed the ability to produce fissile material for nuclear weapons" (Jerusalem Post, 14 July, 2014).

Extract-5 A history of hiding sensitive nuclear work from UN inspectors has kept international suspicions about Iran's nuclear program high and heightened the risk of a new Middle East war should diplomacy fail to yield a long-term settlement (Washington Post,15 July, 2014).

Extract-6 Tehran denies allegations from Western powers and their allies that it is developing a nuclear-weapons capability behind the screen of a declared civilian atomic energy programme (The Guardian, 3 July, 2014).

\subsection{Data Analysis and Discussion at Meso Level}

Media seek to manipulate the public belief and ideology regarding different issues. In this respect, the wording of political texts has a crucial role. According to Machin \& Mayer (2012), media try to persuade subordinate groups to accept their moral, political, and cultural norms which leads to the concept of hegemony. However, in order for people to accept these values and norms, they have to be legitimate; this legitimation is normally achieved through language and talk as an important characteristic in a democratic society.

In this study, attempt has been made to show how the Iranian and the Western media through discursive devices of argumentation and persuasion are trying to make their audience believe whether Iran's nuclear program is peaceful or otherwise. In the following, a few extracts from the Iranian and then a few from the Western media are provided to see how they try to achieve this goal.

\section{Iranian Media Extracts}

Extract-7 We are willing to provide assurances of the exclusively peaceful nature of our nuclear program, Araqchi said. (Press TV, 14 June, 2014).

Extract-8 The IAEA has conducted numerous inspections of Iran's nuclear facilities, but has never found any evidence that Iran's nuclear program has been diverted to nuclear weapon products (Press TV, 14 June, 2014).

Extract-9 Inspectors of the IAEA have repeatedly emphasized that what Iran is doing is peaceful (Press TV, 14 June, 2014).

Extracr-10 In a recent article published in the Washington Post, U.S. Secretary of State John Kerry clearly declared that Iran has completely fulfilled its commitments over the past few months (Tehran Times, 2 July, 2014).

Extract-11 Expressing optimism for a deal to be struck, William Hague, Britain's foreign secretary, said that the disagreements were narrow and that the talks have been very detailed (IRDIPLOMACY, 11 Nov, 2014).

As can be seen in the above extracts, the Iranian media have tried to make audience believe that Iran's nuclear programs are peaceful. In this regard, they have based their argumentation on the IAEA repeated inspections as well as acknowledgements of the peaceful nature of the nuclear sites by the Western officials. The phrases Inspectors of the IAEA have repeatedly emphasized and numerous inspections of Iran's nuclear facilities lead the readers' minds to the fact that Iran has been abiding by the international rules and the Western officials' claims otherwise are just political rhetoric as a means to maintain their hegemony.

The phrases below from the Iranian media extracts try to persuade the readers that Iran has been fully cooperating in the course of the nuclear negotiations in order to remove any suspicions regarding its nuclear activities: 
- We are willing to provide assurances

- Iran has completely fulfilled its commitments

- the disagreements were narrow

\section{Western Media Extracts}

Extract-12 Iran denies wanting nuclear weapons but many in the international community suspect otherwise (Washington post, 18 December, 2014).

Extract-13 It would take Iran a year ...to produce fuel for a bomb (The Guardian, 8 April, 2014).

Extract-14 The Arak research reactor remains a concern since byproducts could be used to create nuclear weapons (New York Times, 29 May, 2014).

Extract-15 In Geneva talks...dangerous concessions were made to the Iranian regime (The Guardian, 24 Nov, 2014).

Extract-16 The ability of the international community to constrain Iran's $R \& D$ cannot be guaranteed "with even 90 percent assurance. Iran nuclear deal 'loophole' may allow off-site reactor work (Jerusalem post, 14 June, 2014).

Extract-17 Zarif said other conditions could be inserted into a deal that would give extra assurances to the international community that Iran could not make a nuclear weapon quickly (Washington Post, 15 July, 2014).

As the above extracts show, the Western media have tried to argue that Iran is desperately trying to achieve nuclear weapons. In fact, they base their argumentation on the hypothesis that Iran might one day produce nuclear weapons. This is clear in the phrases below:

- It would take Iran a year

- could be used to create nuclear weapons

- Iran nuclear deal loophole may allow off-site reactor work.

The use of the modal verbs shows that the report producers without having any concrete information are trying to occupy the readers' minds with this idea that Iran's nuclear program is intended to produce nuclear weapons and if Iran is not prevented from doing so, the whole world will be insecure.

The following statements from the Western media extracts show a strikingly different ideological perspective.

- The Arak research reactor remains a concern...

- Dangerous concessions were made to the Iranian regime...

- Many in the international community suspect...

In the above statements, the words concern and dangerous attitudinally direct the readers' minds towards Iran's attempts to produce nuclear bombs. The reporting verb remains implicitly refers to the Western countries' attempts to solve the problem which have failed. Besides, the word regime adds to the negativity the reporter has created. Using quantification in many in the international community..., the attributed proposition is associated with a significantly large number of governments without referring to the exact number. The verb suspect shows a negatively opinion-based orientation towards Iran, implying that Iran is trying to endanger the world peace.

\subsection{Data Analysis and Discussion at Macro Level}

The analysis of the Western media at meso level revealed instances of how the writers persuaded the readers in accepting the possible insecure nature of Iran's nuclear program. At macro level, an attempt is made to show how the media try to generate value in their news texts. In this respect, this study is concerned with the selection and omission of certain topics on the part of the media.

According to Perrin (2012) "selection of certain topics... and the omission of others" (p. 136) is a strategy by media which manifests their stance. He further points out that even though "the selected variants appear in the text product, the omissions do not" (136) which can be inferred through comparative, cross contextual analyses. The following extracts present a few cases in point.

\section{Iranian Media Extracts}

Extract-18 Kerry's remarks show that Iran is fully committed to the Geneva deal, but according to his view, the country must prove that its nuclear activities will not create any concerns in the future (Tehran Times, 2 July, 2014). 
Extract-19 It would be tragically shortsighted if illusions were to derail progress, Araqchi said. (Fars News, 14 June, 2014).

Extract-20 The western countries, especially the US, have sought excessive demands from Iran in their talks in Vienna. Although they have not conceded any privileges to Iran, they are demanding Iran to take new measures in their favor. They have taken the Iran-world powers talk hostage to make Iran stop some of its nuclear activities in lieu of the removal of certain sanctions (Fars News Agency, 17 May, 2014).

As can be seen in the above extract (18) from the Iranian media, the journalist insists on Iran's commitment to the rules although he distances himself from the opposed view by Kerry through according to. In the next extract (19), the journalist seems to be warning the Western side to take a realistic view at the issue. In the extract (20), the journalist criticizes the Westerners on their unreasonable demands for Iran to put an end to some of its activities. He mentions that the Westerners' demand is excessive and creates a halt in the negotiations progress. However, he does not refer to the fact that every country keeps secret some strategic actions which creates complexities in the international relationships. Therefore, it is neither surprising nor problematic that Western countries worry about Iran's nuclear program.

\section{Western Media Extracts}

Extract-21 Rouhani decisively advances Iran's nuclear program with strategy of deception (Washington Post, 24 Nov, 2014).

Extract-22 The mooted accord is aimed at eradicating fears that Iran might develop nuclear weapons under the guise of its civilian program after a decade of rising tensions and threats of war (The Guardian, 15 July, 2014).

Extract-23 A senior Obama administration official said Saturday that Iran continues to take "inadequate and unworkable" positions on the future of its nuclear program (New York Times, 12 July, 2014).

Extract-24 The United States argues that much of Iran's infrastructure for producing nuclear fuel must be dismantled to significantly extend the time that Iran would need to produce a weapon (Washington Post, 12 June, 2014).

Extract-25 Tehran denies allegations from Western powers and their allies that it is developing a nuclear-weapons capability behind the screen of a declared civilian atomic energy programme (The Guardian, 3 July, 2014).

As it is revealed in the above extracts from the Western media, using attitudinally negative terms such as deception, they try to make the readers believe that Iran's nuclear activities, rising likelihood of war, are dangerous and that Iran has to be stopped from making further advancements. However, they never refer to the fact that some of the Western countries have produced and employed several generations of nuclear weapons, the most violent of which being the one used by the U.S. against Japan in the second world war. Apart from that, they never refer to the results of the numerous inspections of the Iranian nuclear activities by the IAEA inspectors suggesting lack of any deviation evidence and the cooperation Iran has made in this regard.

\section{Quantitative Analysis}

Based on the progression model, the way journalists employ in order to present their argumentation and persuade their readers whether Iran's nuclear activities are peaceful or unpeaceful was studied. The following figure 1 clearly shows us the difference between the Iranian and Western journalists in this regard. 


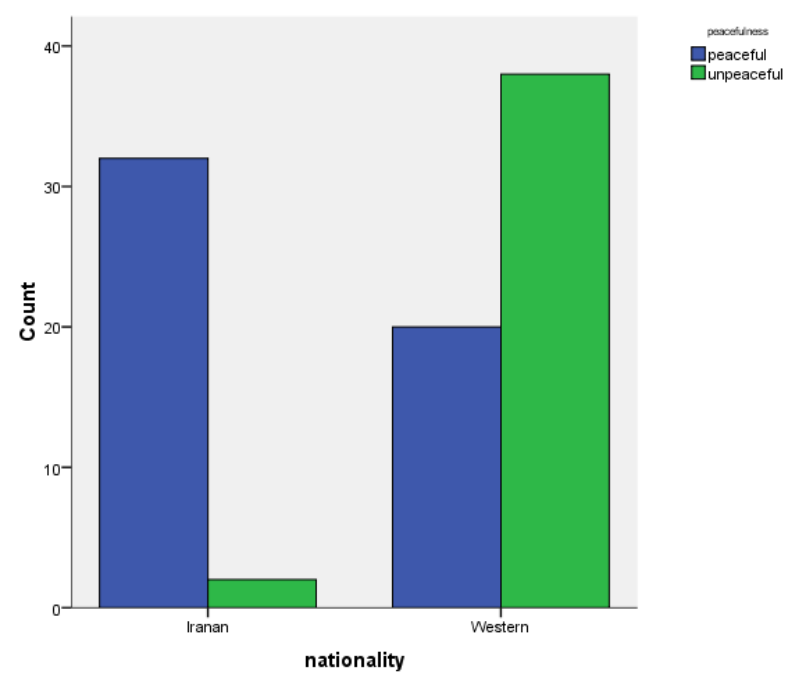

Figure 1. Distribution of (Un)peacefulness claims in Iranian and Western media

The table below depicts the total number of the times each side has employed terminologies regarding the peacefulness or unpeacefulness of Iran's nuclear activities.

Table 1. Descriptive statistics of (un)peacefulness

\begin{tabular}{|c|c|c|c|c|c|}
\hline & & & peaceful & unpeaceful & Total \\
\hline \multirow[t]{8}{*}{ nationality } & Iranian & Count & 32 & 3 & 34 \\
\hline & & $\%$ within nationality & $94.1 \%$ & $5.9 \%$ & $100.0 \%$ \\
\hline & & $\%$ within peacefulness & $61.5 \%$ & $5.0 \%$ & $37.0 \%$ \\
\hline & & $\%$ of Total & $34.8 \%$ & $2.2 \%$ & $37.0 \%$ \\
\hline & Western & Count & 20 & 38 & 58 \\
\hline & & $\%$ within nationality & $34.5 \%$ & $65.5 \%$ & $100.0 \%$ \\
\hline & & $\%$ within peacefulness & $38.5 \%$ & $95.0 \%$ & $63.0 \%$ \\
\hline & & $\%$ of Total & $21.7 \%$ & $41.3 \%$ & $63.0 \%$ \\
\hline \multirow[t]{4}{*}{ Total } & & Count & 52 & 40 & 92 \\
\hline & & $\%$ within nationality & $56.5 \%$ & $43.5 \%$ & $100.0 \%$ \\
\hline & & $\%$ within peacefulness & $100.0 \%$ & $100.0 \%$ & $100.0 \%$ \\
\hline & & $\%$ of Total & $56.5 \%$ & $43.5 \%$ & $100.0 \%$ \\
\hline
\end{tabular}

In the Iranian media the words and phrases indicating the peaceful nature are as follows: peaceful 9 times, peaceful nuclear rights 4 times, nuclear rights 3 times, nuclear activities 2 times, nuclear program 7 times, nuclear talks 4 times, and nuclear deal 3 times. Also, the terms nuclear weapons, nuclear bombs, and concern were met with frequencies of 3 altogether as to the unpeaceful nature in the Iranian media.

In the Western media, on the other hand, peaceful 5 times, peaceful energy purposes 2 times, nuclear fuel 3 times, nuclear activities 4 times, nuclear capabilities 2 times, and nuclear talks 4 times comprised the peaceful class of terms. Also, for the unpeaceful terms and phrases in these media, nuclear weapons 18 times, atomic weapons 5 times, atomic bombs 4 times, concern 3 times, suspicion and suspect 5 times, and threat of war 3 times were met.

For the Iranian media, $94 \%$ of the terms indicate peacefulness and nearly $6 \%$ show unpeacefulness. This proportion is reverse for the Western media since their use of terms indicating Iranian nuclear program peacefulness is only $34 \%$ whereas their unpeacefulness terms in this regard is $65 \%$. Therefore, the analysis reveals a striking difference in the way Iran's nuclear program and the country's motives for pursuing it are constructed in the two sub-corpora $(p=.000)$. 


\section{Discussion}

This paper presented a critical discourse analysis of news texts published by some Iranian and Western online media dealing with the long-running international dispute over Iran's nuclear program. The study adopts Perrin's (2012) progression analysis framework to investigate and compare stancing patterns in the corpus in three levels of micro, meso, and macro which lead the public mind towards the direction beneficial to the related powers.

In political texts, the writers usually come up with lots of argumentation in order to establish their beliefs in the readers' minds. To do so, they stick to explicit and implicit assumptions and lead up to conclusions. In order for a CDA analyst to uncover the writer's ideological and political stance, the textual and intertextual features embedded in the texts can be illuminating. Therefore, in the present study, the textual features of peacefulness and unpeacefulness claims (micro level) as well as intertextual discursive strategies of persuasion and argumentation (meso level) were employed. Also, some issues, ignored by the media, were referred to (macro level) which show their intentions to generate value in the information market based on the national and international benefits of their countries.

Looking at the discursive argumentation devices used by the Iranian side shows that they reiterated the fact that the repeated inspections of the Iranian nuclear sites by the IAEA inspectors (e.g., extract 8 ) had proved the peacefulness of Iran's activities and emphasized a lack of evidence of any deviation from the NPT regulations.

The Western side, however, problematized different aspects of this complex problem implying that Iran is trying to achieve nuclear weapons and that Iran is keeping on the activities under the guise of civilian purposes(e.g., extracts 21 and 25), but they never stressed the acknowledgements of the IAEA regarding the peacefulness of Iran's nuclear activities. In their argumentation, they used a lot of modal verbs of probability (e.g., extract 14) and never offered any concrete information as a proof to their remarks regarding the Iranian nuclear issue and just expressed their hunches.

In terms of persuasion, as a tenet of CDA, both sides provided the readers with promisingly justifying actions in order to create a sense of credulity in them. This is all in line with the link van Dijk (1995) drew between language, power, and ideology. In other words, the journalists have used their specific journalistic discourse in order to produce and maintain their intended ideologies regarding the Iranian nuclear issue in their readers' minds, so that their institutionalized short-term as well as long-term goals can be fulfilled which benefits the powers to maintain their hegemony.

In this respect, the Iranian media tried to convince their readers that Iran has been fully cooperating in the course of the negotiations in order to reach an agreement (e.g., extract 10). They also expressed the differences to be narrow (e.g., extract 11) in order to create an optimistic atmosphere in society so that the negotiations could be driven forward. In fact, they tried to enforce their social power in manipulating the public mind in the interest of the Iranian government.

The Western media, on the other hand, tried to convince their readers that Iran is a dangerous country (e.g., extract 15). In this regard, they employed attitudinally negative terms about the Iranian nuclear sites, casting doubt on their peaceful nature (e.g., extract 4). In fact, they tried to picture Iran as an unruly country as a means to maintain their hegemony in the world through getting their political and cultural values accepted by the readers.

\section{Conclusion}

As van Dijk (1995) pointed out, CDA approach explicitly positions itself on the side of the dominated and against dominating groups. In this respect, as this study is based on CDA approach, the researchers took the side of the Iranian media supporting Iran's nuclear program. The researchers believe that the superpowers of the world are treating the weak nations cruelly and that Iran is among them. While according to the Western officials, Iran has conformed to the international rules, still the superpowers try to prevent it from reaching modern technologies such as nuclear energy. It is, of course, to be noted that according to Watson (1994), research is not value free since researchers inevitably influence their findings. This can again be related to van Dijk's (1995) idea that cognitive influence leads to the subjective interpretations. Therefore, the researchers are open to criticism with regard to their interpretations of the media extracts conducted in data analysis section.

The findings of this research are hoped to benefit teachers in their teaching of texts. They should be reminded that texts are carriers of attitudes and ideologies and therefore, provide students with the required critical language awareness to understand the ideological orientation of texts.

In addition, the results of this study have a significant implication for the discussion of stance-taking in relation to the notion of journalistic neutrality. As it is, media mostly claim neutrality while having their own political 
stances. As a result, the readers' world views are influenced by the ideas and beliefs of the media unconsciously.

In sum, the findings of this research, based on an analysis of stancing on micro, meso, and macro levels, show that the events are not represented in the newspapers as they are in reality, but go through journalistic stancing practices which are presented in either linguistic means or their absence, making stance "opaque to the analyst" (Hyland, 2005, p. 177). Therefore, it supports Perrin (2012)'s view that investigation of stancing is process and not product oriented.

It is plausible that a number of limitations may have influenced the results obtained. To begin with, only four of the Iranian media and four of the Western media were compared and contrasted. A larger number of the media, especially from a wider western geography, seem to contribute to more accurate results. The other issue was the limited number of the extracts analyzed. If the number of the extracts could be increased, the results might be more reliable and generalizable.

This study gives a preliminary understanding about the way journalists make use of lexicon to influence their readers' minds regarding the Iranian nuclear issue and the association between lexical choices and political stances. Further researches can be done including the grammatical devices to see how language can be used to direct readers' minds to special directions.

\section{References}

Baker, P. (2008). A useful methodological synergy? Combining critical discourse analysis and corpus linguistics to examine discourses of refugees and asylum seekers in the UK press. Discourse \& Society, 19(3), 273-306. http://dx.doi.org/10.1177/0957926508088962

Behnam, B., \& Mahmoudy, B. (2013). A critical discourse analysis of the reports issued by the International Atomic Energy Agency (IAEA) Director General. Iran's nuclear program during the last decade. Theory and Practice in Language Studies, 12(3), 2196-2201. http://dx.doi.org/10.4304/tpls.3.12.2196-2201

Bell, A. (2001). Back in style. Reworking audience design. In P. Eckert \& J. R. Rickford (Eds.), Style and Sociolinguistic Variation (pp. 139-169). Cambridge: Cambridge University Press.

Bell, A., \& Garrett, P. (1998). Approaches to media discourse. Oxford: Blackwell Publishers Ltd.

Economou, D. (2008). Evaluation in news images. Comparative studies of the detention of refugees. In P. R. R. White \& E. A. Thomson (Eds.), Communicating conflict. Multilingual case studies of the news media (pp. 253-280). London: Continuum.

Fairclough, N. (1995a). Media discourse. London: Arnold.

Fairclough, N. (1995b). Critical discourse analysis: The critical study of language. London: Longman.

Fairclough, N., \& Wodak, R. (2007). Critical discourse analysis. In van T. A. Dijk (Ed.), Discourse as social interaction (pp. 258-284). London: SAGE Publications.

Fowler, R. (1991). Language in the news: Discourse and ideology in the press. London: Routledge.

Hodge, R., \& Kress, G. (1979). Language as ideology. New York: Routledge.

Hyland, K. (2005). Stance and engagement. A model of interaction in academic discourse. Discourse Studies, 7(2), 173-192. http://dx.doi.org/10.1177/1461445605050365

Izadi, F., \& Saghaye, B. H. (2007). A discourse analysis of elite American newspaper editorials: The case of Iran's nuclear program. Journal of Communication Inquiry, 31(2), 140-165. http://dx.doi.org/10.1177/0196859906298073

Machin, D., \& Mayr, A. (2012). How to do critical discourse analysis: A Multimodal introduction. Retrieved from http://www.books.google.com

Perrin, D. (2003). Progression analysis (PA). Investigating writing strategies at the workplace. Journal of Pragmatics, 35(6), 907-921. http://dx.doi.org/10.1016/S0378-2166(02)00125-X

Perrin, D. (2011). Collaborative text-picture production strategies of TV journalists. Journal of Pragmatics, 43(7), 1865-1875. http://dx.doi.org/10.1016/j.pragma.2010.09.023

Perrin, D. (2012). Strategies of entextualizing stance in newswriting. Discourse, Context \& Media, 1(2-3), 135-147. http://dx.doi.org/10.1016/j.dcm.2012.10.005

Pounds, G. (2010). Attitude and subjectivity in Italian and British hard-news reporting. The construction of culture-specific "Reporter" Voice. Discourse \& Society, 12(1), 106-137. 
http://dx.doi.org/10.1177/1461445609346777

Richardson, J. E. (2007). Analyzing newspapers: An approach from critical discourse analysis. New York: Palgrave Macmillan.

Schultz, I. (2007). The journalistic gut feeling. Journalism Practice, 1(2), 190-207.

Shojaei, A., Youssefi, K., \& Shams Hosseini, H. (2013). A CDA approach to the biased interpretation and representation of ideologically conflicting ideas in Western printed media. Journal of Language Teaching and Research, 4(4), 858-868. http://dx.doi.org/10.4304/jltr.4.4.858-868

Siegel, J., \& Barfroush, S. (2013). Media coverage of Iran's nuclear program. Ananalysis of U.S. and U.K. coverage, 2009-2012. Center for international and security studies at Maryland, School of public policy, University of Maryland.

Stmaou, A. G. (2001).The representation of non-protesters in a student and teacher protest: A critical discourse analysis of news reporting in a Greek newspaper. Discourse \& Society, 12(5), 653-680. http://dx.doi.org/10.1177/0957926501012005005

Talebinejad, M. R., \& Shahi, M. (2014). Frame labeling of competing narratives in journalistic translation. Journal of Research in Applied Linguistics, 5(2), 23-40.

Thelta, P. (1997). Evaluated entities and parameters of value in academic research articles. English for Specific Purposes, 16, 101-118. http://dx.doi.org/10.1016/S0889-4906(96)00022-1

van Dijk, T. A. (1995). Aims of critical discourse analysis. Japanese Discourse, 1, 17-27.

van Dijk, T. A. (1998). Towards a theory of context and experience models indiscourse processing. In van H. Oostendorp \& S. Goldman (Eds.), The construction of mental models during reading. Hillsdale, NJ: Erlbaum.

Watson, T. J. (1994). In search of management. London: Routledge.

\section{Copyrights}

Copyright for this article is retained by the author(s), with first publication rights granted to the journal.

This is an open-access article distributed under the terms and conditions of the Creative Commons Attribution license (http://creativecommons.org/licenses/by/4.0/). 